\title{
CORRIGENDUM
}

\section{Permian basinal ammonoid sequence in Nanpanjiang area of South China-possible overlap between basinal Guadalupian and platform-based Lopingian-CORRIGENDUM}

\author{
Zuren Zhou
}

doi: 10.1017/jpa.2016.128, Published by Cambridge University Press, 26 April 2017.

After publishing this Memoir online, Dr. Matthew E. Clapham wrote to the author, Zuren Zhou, that "the name Glenisteroceras has already been used, in 1957, for an Ordovician nautiloid (Glenisteroceras Flower, 1957).”

The name Glenisteroceras was incorrectly applied throughout the Memoir to describe this species. The author would like to apply a new terminal, -ites for the genus. The newly named genus should be Glenisterites, with type species Glenisterites sidazhaiensis Zhou, 2017. The author apologizes for this error.

\section{Reference}

Zhou, Z., 2017, Permian basinal ammonoid sequence in Nanpanjiang area of South China - possible overlap between basinal Guadalupian and platformbased Lopingian: Journal of Paleontology, v. 91, S74, p. 1-95. 